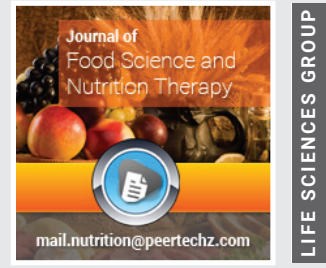

\title{
The comparison of nutritional and physical activity statuses in students of Audiology and Nutrition \& Dietetics
}

\section{Ayşe Güneş Bayir* and Zeynep Hüdanur Alban}

Received: 24 December, 2019

Accepted: 25 February, 2020

Published: 26 February, 2020

*Corresponding author: Ayse Gunes-Bayir, Assistant professor, Department of Nutrition and Dietetics, Faculty of Health Sciences, Bezmialem Vakif University, Silahtarağa Caddesi No: 198, 34065 Eyüp, Istanbul, Turkey, Tel: +90 21245317 00-4596;

E-mail:agunes@bezmialem.edu.tr

Keywords: Nutritional status; Food frequency; Physical activity; University students

https://www. peertechz.com

Check for updates

Department of Nutrition and Dietetics, Faculty of Health Sciences, Bezmialem Vakif University, Istanbul, Turkey

\section{Abstract}

This study aimed to assessment and compare nutritional and physical activity status of Nutrition\&Dietetics and Audiology Departments.

The study was carried on students of Bezmialem Foundation University Faculty of Health Sciences Nutrition\&Dietetics (experimental group) and Audiology (control group) Departments in 2016/2017 academic year. The survey included socio-demographic characteristics, 24-h recall Food Consumption Record, Food Frequency Questionnaire to determine nutrition and physical activity. Body Mass Index, waist circumference and body fat mass ratios were measured by bioelectrical impedance device.

Overall, $220(66 \%)$ students participated, $125(84 \%)$ from experimental group and $95(46 \%)$ from control group. $75 \%$ of experimental group and $73 \%$ of control group were calculated as normal weight and mean body fat ratios were normal ( $24.3 \%$ and $22.8 \%$, respectively). However, energy, water, carbohydrates, some vitamins and minerals were inadequate for two groups and fat consumption levels were high. $34 \%$ of those in control group had skipped breakfast meals, and they had unhealthy attitudes like chocolate and biscuits. Daily dairy products consume were found experimental group more than control group ( $p<0.05$ ). $55 \%$ of experimental group and $58 \%$ of control group had regular physical activity.

Health professionals need to be more conscious about healthy life, which includes adequate-balanced nutrition and regular physical activity.

\section{Introduction}

Today, changes in lifestyle habits, including nutrition and physical activity habits, that the prevalence of obesity for public health caused a significant increase in the last 20 years considered to be a serious threat in Turkey $[1,2]$. In order to stop this increase, it is recommended to provide public health education including balanced nutrition and physical activity [2].

Students have more hardship in making healthy food choices with the increased independence reason of transition from high school to university [3]. In the transition period to adulthood, where models of healthy behaviours are formed, university students are exposed to unhealthy eating habits [4]. It is known that unhealthy eating habits are also affected by the inadequate exercise habits, poor time management and increasing stress caused of education life (university lifestyle, exams, etc.) $[3,5,6]$. At the same time, it has been shown to be associated with students are uninformed about healthy food choices, increasing financial concerns and health problems $[3,7]$. In addition, it seems that the nutritional environment of the university (such as inadequate options such as cafeteria, refectory) affects the adoption of unhealthy eating habits [8].

According to the qualitative research, most of the university students' eating habits were considered unhealthy [4,9-11]. A study conducted in Finland found that university students are fond of unhealthy foods [4]. According to research conducted at 5 UK universities, male students are consume based on ready meals, alcohol and red meat [9]. In another study, male students adopted the Western-type diet model and women adopted the vegetarian / low-calorie diet model at private universities in Lebanon [10]. It has been found that students studying at the 
state university in Bangladesh are eating unhealthy due to various reasons such as nutrition education and conditions of nutrition [11].

The impact of physical activity on health behavior patterns, such as eating habits also known [12-14]. Regular physical activity has positive effects on physical, social and mental health $[12,13,15,16]$. On the other hand, appropriate and regular physical activity; reduces the risk of developing chronic disease, improves quality of life and well-being, and improves cognitive mechanism [15-19]. The World Health Organization (WHO) recommends that adults aged 18 to 64, exercise in moderate physical activity for at least 150 minutes per week or severe physical activity for at least 75 minutes per week [20]. It was seen that physical activity decreased during the transition period from high school to university especially in males [21,22].

The assessment studies have accomplished on university students of health professions about nutrition and physical activity in Turkey [22-25]. According to the studies it is observed that students have unhealthy behavior models although they take courses in health field [22,24]. However, interdepartmental nutrition and physical activity assessment and comparison studies were found to be insufficient $[22,24]$. There is no study on Audiology (ADY) and Nutrition \& Dietetics (ND) students in the literature. Accordingly, the study was planned and conducted to determine and compare the nutritional and physical activity status of the students of ND Department and ADY Department of the Faculty of Health Sciences.

\section{Materials and methods}

\section{Ethical aspects of research}

This study was approved by Bezmialem Vakif University Ethics Committee for Non-Interventional Studies (No: 54022451-050.05.04-9/89). In line with the Helsinki Declaration, the students who were invited to the study were informed about the purpose, expectations and the necessary information about the research and then received verbal and written consent to participate in the study.

\section{Formation of research groups}

In the 2017-2018 academic year, the students of Bezmialem Vakif University Faculty of Health Sciences (Istanbul, Turkey), ND (experimental group, $n=149$ ) and ADY (control group; $n=209)$ Departments formed the study groups $(n=358)$.

\section{Data collection tools}

In the study, an including the scales a modified questionnaire from Bayır and Güçlü (2018) was conducted by the researcher's face-to-face interviews with the participants. The survey consists of 5 separate sections; socio-demographic data, anthropometric measurements, nutritional habits, nutritional status assessment scales that used from 24 -h recall Food Consumption Record and Food Consumption Frequency Form. In addition, a questionnaire was used to evaluate physical activity [22]. Anthropometric measurement applied to each participant with the same tools in the practice laboratory was performed by trained researchers. Height measurement was measured wall-mounted height scale measuring cylinder (ADE; Tarti medical, Istanbul, Turkey), body weight and body fat mass (BFM) ratio analysis was measured bioelectric impedance analyzer (BIA) (Tanita MC 780; Tarti medical, Istanbul, Turkey) and waist circumference was measured with tape (ADE; Tarti medical, Istanbul, Turkey) were recorded. Body Mass Index (BMI) values were calculated by weight $(\mathrm{kg}) /$ height $^{2}\left(\mathrm{~m}^{2}\right)$ and classified according to WHO's BMI standards [26]. In this classification, BMI is less than $18.5 \mathrm{~kg} / \mathrm{m} 2$ were accepted as underweight, $18.5-24.9 \mathrm{~kg} / \mathrm{m}^{2}$ were normal weight, 25 to $29.9 \mathrm{~kg} / \mathrm{m}^{2}$ were overweight (pre-obese), $30.0-34.9 \mathrm{~kg} /$ $\mathrm{m}^{2}$ were first degree obese, $35-39.99 \mathrm{~kg} / \mathrm{m}^{2}$ were II. degree and $\geq 40.00 \mathrm{~kg} / \mathrm{m}^{2}$ were III. degree was determined to be obese. The waist circumference that determines the risk of abdominal obesity was determined by WHO as $88 \mathrm{~cm}$ and above for women and $102 \mathrm{~cm}$ and above for men [26]. In the questionnaire that was contained main and intermediate meals, skipping meals, frequency of eating out, frequency of fast food consumption, daily water consumption, smoking and alcohol habits, the most preferred cooking methods, frequently consumed food groups etc. used in the research. 24hour dietary recall [27], was used with all amounts of food and beverages consumed by the participants. Food frequency questionnaire (FFO) [27], was used to determine the frequency of food consumption and food groups by day, week or month. Forms were filled using visual materials (My plate food replicas; Nasco, Wisconsin; USA) (Figure 1). Questions were asked to determine the state of physical activity.

\section{Data analysis}

The data obtained from FFQ and 24-hour dietary recalls were analyzed by Nutrition Information System (BeBIS; Pacific Electrical, Electronic and Environmental Technology Products Industry and Trade Limited Co., Istanbul, Turkey). BeBIS is a

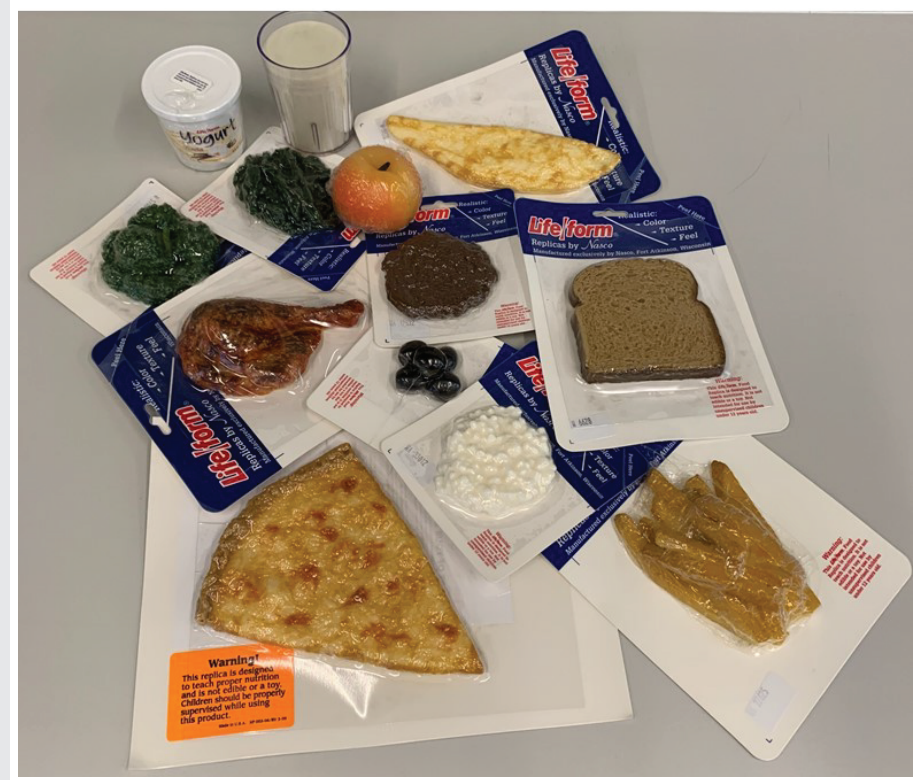

Figure 1: My Plate Food Replicas Used as Visual Materials. 
software program, by which can be analyzed diet forms and calculates over 20,000 nutrients, portion sizes, over 450 dishes and ingredient lists, and over 130 nutrients (macronutrients, pulp, vitamins, minerals, amino acid and fatty acid varieties, vegetable protein etc.). In addition, the portion amounts of the participants can be calculated and compared with the standard portions of BeBIS.

Statistical analysis of all data obtained from the study was performed using IBM SPSS (version 22.0) software program. Qualitative data were calculated with mean, median, minimum-maximum and standard deviation. Chi-Square, Mann-Whitney and Student-T tests were used to compare the groups. The results were considered statistically significant when the $P$ value was less than or equal to 0.05 .

\section{Results and discussion}

More than half of the students $(66 \%, \mathrm{n}=220)$ participated in the study conducted at Bezmialem Vakif University, Faculty of Health Sciences. A total of $46 \%$ of the participants were from the ADY Department $(n=95)$ and $84 \%$ from the ND Department $(n=125)$.

The data on the socio-demographic and anthropometric characteristics of the students participating in the research are presented in Table 1 as a comparison of the sections. ND and ADY students are between 18 and 23 years old. According to the WHO-defined BMI classification [26], 15\% $(n=19)$ of the ND students were underweight, $75 \%(n=94)$ were normal, $6 \%$ $(n=8)$ were pre-obese, $2 \%(n=3)$ were I. degree obese, and $1 \%$ $(n=1)$ were II. degree obese found in ranges. Similarly, $12 \%$ $(n=11)$ of ADY students were underweight, $73 \%(n=69)$ were normal, $13 \%(n=12)$ were pre-obese, $2 \%(n=2)$ were I. degree obese, and $1 \%(n=1)$ were II. degree obese found in ranges. No differences were found which median BMI (min-max) values of ND students were $20.9 \mathrm{~kg} / \mathrm{m}^{2}(15.8-38.8)$ and ADY students were $21.3 \mathrm{~kg} / \mathrm{m}^{2}(16.7-38.8)(p=0.323)$. According to TBSA-2010 report, underweight ones were $5.1 \%$, normal ones were $57.7 \%$, pre-obese ones were $26.9 \%$ and obese subjects were $9.7 \%$ when the average BMI values of individuals between 19-30 [29]. In a study, the BMI classification of university students was found to be like this study [30]. When the median (minmax) measurement of BFM ratio of BIA device were examined; ND Department was found to be $23.4 \%(3.8-39.6)$, while the ADY Department was found to be $22.60 \%(4.5-45.6)(p=0.144)$. In another study conducted with 229 students in the Faculty of Medicine, it was found that the mean BFM ratio was similar [31]. When the waist circumference of women with $\geq 88 \mathrm{~cm}$ and men with $\geq 102 \mathrm{~cm}$ are examined, it is respectively $12 \%(n=15)$ and $8.4 \%(n=8)$ of ND and ADY students. A cross-sectional study of 1934 university students in a university where is in Jordan found that the waist circumference of $\geq 88 \mathrm{~cm}$ in females and $\geq 102 \mathrm{~cm}$ in males of the students was $4.9 \%(n=90)$ [32] Graphic 1.

When the nutritional habits of the students were examined, $91 \%$ of the students of the ND $(n=111)$ and ADY $(n=86)$ Department skipped meals. On the other hand, 19\% $(n=21)$ of ND students who skipped the breakfast meal, while $34 \%$
Table 1: Socio-demographic and Anthropometric Characteristics of ND and ADY Departments' Students.

\begin{tabular}{|c|c|c|c|c|c|}
\hline & \multicolumn{2}{|c|}{$\begin{array}{l}\text { Nutrition \& Dietetics } \\
\text { (experimental group) }\end{array}$} & \multicolumn{2}{|c|}{\begin{tabular}{|c|} 
Audiology \\
(control group)
\end{tabular}} & \multirow[t]{2}{*}{$P$ value } \\
\hline Class years & $\mathrm{n}$ & $\%$ & $\mathrm{n}$ & $\%$ & \\
\hline $1^{\text {st }}$ Class & 53 & 42 & 38 & 40 & \multirow{4}{*}{$0.36^{*}$} \\
\hline $2^{\text {nd }}$ Class & 39 & 31 & 22 & 23 & \\
\hline $3^{\text {rd }}$ Class & 28 & 22 & 30 & 32 & \\
\hline $4^{\text {th }}$ Class & 5 & 4 & 5 & 5 & \\
\hline \multicolumn{6}{|l|}{ Socio-demographic Characteristics } \\
\hline Years (min-max) median & \multicolumn{2}{|c|}{$(18-23) 19$} & \multicolumn{2}{|c|}{$20(18-23)$} & $<0.05^{\star \star}$ \\
\hline Gender & $\mathrm{n}$ & $\%$ & $\mathrm{n}$ & $\%$ & \\
\hline Female & 117 & 94 & 80 & 84 & \multirow{2}{*}{$<0.05^{\star}$} \\
\hline Male & 8 & 6 & 15 & 16 & \\
\hline \multicolumn{6}{|l|}{ City } \\
\hline İstanbul & 107 & 86 & 76 & 80 & \multirow{2}{*}{$0.2^{\star}$} \\
\hline Other & 18 & 14 & 19 & 20 & \\
\hline \multicolumn{6}{|l|}{ Anthropometric Characteristics } \\
\hline \multicolumn{6}{|l|}{ Body Mass Index (BMI) $\left(\mathrm{kg} / \mathrm{m}^{2}\right)$} \\
\hline Underweight (<18.5 kg/m²) & 19 & 15 & 11 & 12 & $0.438^{*}$ \\
\hline Normal $\left(18.5-24.9 \mathrm{~kg} / \mathrm{m}^{2}\right)$ & 94 & 75 & 69 & 73 & $0.667 *$ \\
\hline Pre-obese $\left(25-29.9 \mathrm{~kg} / \mathrm{m}^{2}\right)$ & 8 & 6 & 12 & 13 & $0.111^{\star}$ \\
\hline $1^{\text {st }}$ Degree Obese $\left(30-34.99 \mathrm{~kg} / \mathrm{m}^{2}\right)$ & 3 & 2 & 2 & 2 & $1^{*}$ \\
\hline $2^{\text {nd }}$ Degree Obese $\left(35-39.99 \mathrm{~kg} / \mathrm{m}^{2}\right)$ & 1 & 1 & 1 & 1 & $1^{*}$ \\
\hline $3^{\text {rd }}$ Degree Obese $\left(\geq 40.00 \mathrm{~kg} / \mathrm{m}^{2}\right)$ & 0 & 0 & 0 & 0 & \\
\hline \multicolumn{6}{|l|}{ Waist Circumference } \\
\hline $\begin{array}{c}\geq 88 \mathrm{~cm} \text { females and } \geq 102 \mathrm{~cm} \\
\text { males }\end{array}$ & 15 & 12 & 8 & 8 & $0.404 *$ \\
\hline $\begin{array}{l}\text { Body Fat Mass Ratio median } \\
\qquad(\text { min-max })\end{array}$ & \multicolumn{2}{|c|}{$23.4(3.8-39.6)$} & \multicolumn{2}{|c|}{$22.60(4.5-45.6)$} & $0.144^{\star \star}$ \\
\hline Total & \multicolumn{2}{|c|}{125} & \multicolumn{2}{|c|}{95} & \\
\hline
\end{tabular}

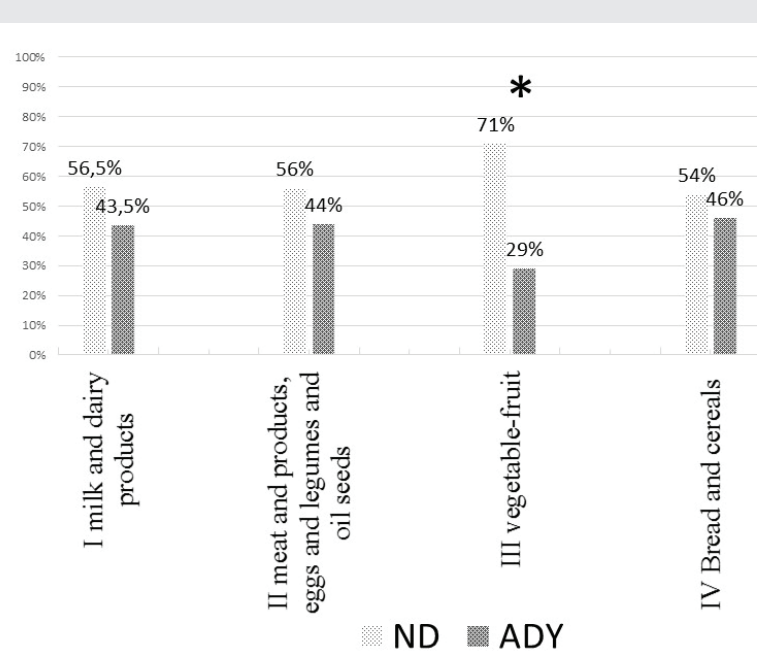

${ }^{*} \mathrm{p}<0.05$ was statistically significant

Graphic 1: Daily Consumption of food groups by ND and ADY Students.

$(n=29)$ of ADY students $(p<0.05)$. This result is consistent with several studies $[22,28,33]$ conducted in Turkey with university students. In our study, $36 \%(n=40)$ of ND students and $47 \%$ $(n=40)$ of ADY students indicated the highest rate of time insufficiency as the reason for skipping meals. In another study, this was found to be the highest cause of lack of time in skipping meals [22]. 94\% $(n=118)$ of ND students and $97 \%$ $(n=92)$ of ADY students consumed snacks. ND students consume mostly dried fruits $(49 \%, n=58)$, fresh fruits $(46 \%, n=54)$ and 
milk-yoghurt $(29 \%, n=34)$ respectively. On the other hand, ADY students mostly chocolate $(51 \%, n=47)$, fresh fruit $(45 \%$, $n=41)$ and biscuits $(34 \%, n=31)$ respectively. It was observed that ND students preferred more the nuts which were healthier with statistically significant than ADY students in consuming snacks $(p<0.01)$. It was found that $21 \%(n=26)$ of ND students and $31 \%(n=29)$ of ADY students consumed fast food 2-3times or more per week. The three most preferred cooking methods were found to be similar in both department students. ND and ADY students were answered respectively; baking 30\% and $29 \%$, boiling $19 \%$ and $22 \%$; frying was $19 \%$ and $22 \%(p<0.05)$.

In nutritional status assessment studies, FFQ [27] and 24-h recall Food Consumption Record [27], scales were found to be good for determining nutritional habits for use in university student populations [34]. Therefore, both scales were used with the Nutrition Information System (BeBIS) and calculated with that. The data obtained using the 24 -h recall Food Consumption Record are shown in Table 2 in detail and comparatively by the average values consumed for both department students. Turkey Nutrition Guide (TUBER) [35] is reported, the average individual daily energy needs $2239 \mathrm{kcal}$ for men and $1786 \mathrm{kcal}$ for women between the ages of 18-29 lower activity. Daily energy intake was found to be $1387 \mathrm{kcal}$ (222-2773) in ND students and $1495 \mathrm{kcal}$ (517-3689) in ADY students, and these values were found to be below the TUBER recommendations. When the protein intake rates of the students are examined, they are $17.2 \%$ and $17.4 \%$, respectively in the ND and ADY departments, in accordance with TUBER recommendations (12\%-20\%) [35]. When the carbohydrate intake rates are examined, they are seen that ND students consume $\mathbf{4 2 . 7 \%}$ and ADY students' rate of $43.4 \%$ and these rates are lower than the recommended range $(45 \%-60 \%)$ [35]. Fat intake rate was found that $39.2 \%$ of ND students and 40.1\% ADY students with an average of above the recommendations (20\%-35\%). TUBER 2016 also stated that adults can provide the daily water requirement by drinking $1500 \mathrm{ml}-2000 \mathrm{ml}$ [35]. When the average of daily water consumption is examined, it is seen that both departments do not reach these values. ND students consumed $1200 \mathrm{ml}$ (200$3000)$ and ADY students consumed $1200 \mathrm{ml}$ (200-2400) of drinking water. The daily fiber intake recommended by the European Food Safety Authority (EFSA) and also TUBER is 25 $\mathrm{g}[35,36]$. ND and ADY students consumed $16 \mathrm{~g}$ to $17 \mathrm{~g}$ of fiber, respectively, and had less consumption than recommended. The recommended daily amount of potassium is 4.7g [35]. ND students consumed $1391 \mathrm{mg}$ of potassium and ADY students consumed $1798 \mathrm{mg}$ of potassium but remained below the recommended level $(p<0.05)$. Likewise, the recommended daily amount of magnesium is $300 \mathrm{mg}$ [35]. ND students consumed $159 \mathrm{mg}$ of magnesium and ADY students consumed $207 \mathrm{mg}$ that remained below the recommended and there was a significant difference between the two departments $(p<0.01)$. The salt consuming was limited by WHO to $5 \mathrm{~g}$ per day [37]. As a result of the study, it was observed that ND students consumed $6.7 \pm 3.2 \mathrm{~g}$ and ADY students consumed $7.4 \pm 3.4 \mathrm{~g}$ salt. The recommended daily intake for vitamin C is 9omg [35]. ND students consumed significantly more to ADY students and approached the reference intake level $(p<0.05)$.
Table 2: Nutrient Consumption of ND and ADY Students.

\begin{tabular}{|c|c|c|c|}
\hline Nutrients & $\begin{array}{l}\text { Nutrition \& Dietetics } \\
\text { (experimental group) }\end{array}$ & $\begin{array}{c}\text { Audiology } \\
\text { (control group) }\end{array}$ & $P$ value \\
\hline Water (ml) & $1200(200-3000)$ & $1200(200-2400)$ & $0.2^{*}$ \\
\hline Energy (kcal) & $1387(222-2773)$ & 1495 (517-3689) & $0.257^{*}$ \\
\hline Protein $(\mathrm{g})$ & $56(6-141)$ & $60(16-37)$ & $0.140^{*}$ \\
\hline$\%$ & $16(7-45)$ & $17(6-34)$ & $0.386^{*}$ \\
\hline Fat (g) & $62.98 \pm 25.15$ & $66.73 \pm 27.82$ & $0.297 * \star$ \\
\hline$\%$ & $40.10 \pm 8.47$ & $39.19 \pm 8.25$ & $0.423^{* *}$ \\
\hline Saturated fatty acid (g) & $23(3-52)$ & $20(4-52)$ & $0.196^{*}$ \\
\hline $\begin{array}{c}\text { Monounsaturated fatty } \\
\text { acid (g) }\end{array}$ & $19(4-59)$ & $19(4-37)$ & $0.968^{*}$ \\
\hline $\begin{array}{l}\text { Polyunsaturated fatty } \\
\text { acid (g) }\end{array}$ & $13(2-43)$ & $16(2-58)$ & $<0.01^{*}$ \\
\hline C18,3 Linolenic acid (g) & $1(0-6)$ & $1(0-8)$ & $0.057 *$ \\
\hline Cholesterol (mg) & $208(0-758)$ & $190(4-1030)$ & $0.495^{\star}$ \\
\hline Carbohydrate (g) & $140(18-451)$ & $149(30-524)$ & $0.204^{*}$ \\
\hline$\%$ & $43 \pm 9$ & $43 \pm 9$ & $0.579 * *$ \\
\hline Fiber (g) & $16(3-40)$ & $17(6-49)$ & $0.617^{*}$ \\
\hline \multicolumn{4}{|l|}{ Vitamins } \\
\hline Vitamin A $(\mu \mathrm{g})$ & 739 (96-5973) & 731 (151-3329) & $0.497^{\star}$ \\
\hline Vitamin E (mg) & $11(2-44)$ & $16(1-57)$ & $<0.01 *$ \\
\hline Vitamin B1 (mg) & $1(0-2)$ & $1(0-1)$ & $0.768^{*}$ \\
\hline Vitamin B2 (mg) & $1(0-3)$ & $1(0-5)$ & $0.895^{\star}$ \\
\hline Niacin equivalent (mg) & $19(2-92)$ & $20(6-44)$ & $0.260^{*}$ \\
\hline Vitamin B6 (mg) & $1(0-3)$ & $1(0-3)$ & $0.583^{*}$ \\
\hline Pantothenic acid (mg) & $3(0-8)$ & $3(1-10)$ & $0.797^{\star}$ \\
\hline Total folic acid $(\mu \mathrm{g})$ & $201(18-511)$ & $198(85-519)$ & $0.903^{*}$ \\
\hline Vitamin B12 $(\mu \mathrm{g})$ & $3(0-52)$ & $3(0-101)$ & $0.121^{*}$ \\
\hline Vitamin C (mg) & $83(5-3773)$ & $71(6-381)$ & $<0.05^{*}$ \\
\hline \multicolumn{4}{|l|}{ Minerals } \\
\hline Sodium (mg) & 2619 (577-10529) & 3049 (872-12697) & $<0.05^{\star}$ \\
\hline Potassium (mg) & $1391(26-3880)$ & $1798(607-4169)$ & $<0.05^{\star}$ \\
\hline Calcium (mg) & $543(46-1376)$ & $531(152-1313)$ & $0.914^{*}$ \\
\hline Magnesium (mg) & $159(1-546)$ & 207 (73-491) & $<0.01^{*}$ \\
\hline Phosphorus (mg) & $888(87-2244)$ & $925(318-1917)$ & $0.769 *$ \\
\hline Iron (mg) & $9(1-21)$ & $9(3-21)$ & $0.609 *$ \\
\hline Zinc (mg) & $8(1-20)$ & $8(2-23)$ & $0.139 *$ \\
\hline Salt (g) & $6(1-17)$ & $7(1-24)$ & $0.136^{*}$ \\
\hline
\end{tabular}

*Mann-Whitney test was used. ** T-test was applied. ( $<<0.05$ was considered statistically significant. $p<0.01$ was considered statistically significant).

The data obtained from the FFQ were evaluated in the I-IV food groups with reference to "Four Leaf Clover Model": (I) milk and milk products; (II) meat and products, eggs and legumes and oil seeds; (III) vegetable-fruit; (IV) bread and cereals. Food group preferences of ADY and ND students are shown in Chart I in detail. Group I Milk and dairy products were consumed by both department students every day (ND (56\%, $n=70)$; $\mathrm{ADY}(57 \%, n=54)$. Group II covers all meat and products, eggs, legumes and oilseeds, and their daily consumption rate is $15 \%(n=19)$ for ND students and $16 \%(n=15)$ for ADY students. When the daily consumption of vegetables and fruits (Group III) was examined, it was found that ND students were $42 \%$ 
$(n=53)$ higher than ADY students $(23 \%, n=22)$ and statistically significant $(p<0.005)$. Bread and cereals (Group IV) consume $65 \%(n=81)$ of ND students and $72 \%(n=68)$ of ADY students daily. The fact that PPS students consume more fruits and vegetables every day (Group III) shows that they have the tendency and awareness towards healthier choices. However, such a result was not seen in consumption of other groups [35].

It was found that $64(45 \%)$ of ND students and $55(58 \%)$ of ADY students in the study were doing regular physical activity. A similar result was obtained in a cross-sectional study of university students [32]. 39 students $(61 \%)$ from ND students and 44 students $(80 \%)$ from ADY students are doing walking regularly.

\section{Conclusion}

According to the results of the study, dietary habits of ADY students consist of unhealthy choices than ND students. Moreover, students of both departments have an inadequateunbalanced diet patterns and not all of them have regular physical activity habits.

ADY and ND students will be among the individuals who are the future healthcare professionals and manage society. For this reason, it is recommended to include more nutrition lessons in the curriculum during the university period and to increase the incentives for healthy nutrition as well as regular physical activity. Further cross-sectional studies are needed to determine the nutritional status and physical activity of students at the Faculty of Health Sciences.

\section{Acknowledgements}

We would like to thank Res. Assist. Ayșegül Yabacı from the Department of Biostatistics at Bezmialem Vakif University who helped the project during the statistical analysis.

\section{References}

1. Alper Z, Ercan I, Uncu Y (2018) A meta-analysis and an evaluation of trends in obesity prevalence among children and adolescents in Turkey: 1990 through 2015. J Clin Res Pediatr Endocrinol 10: 59-67. Link: http://bit.ly/2HYpfix

2. Erem C (2015) Prevalence of overweight and obesity in Turkey. IJC Metabolic Endocrine 8: 38-41. Link: http://bit.ly/2wPxrQ3

3. Deliens T, Clarys P, De Bourdeaudhuij I, Deforche B (2014) Determinants of eating behaviour in university students: a qualitative study using focus group discussions. BMC Public Health 14: 53. Link: http://bit.ly/32sav4T

4. El Ansarı W, Suomınen, S, Samara A (2015) Eating habits and dietary intake: is adherence to dietary guidelines associated with importance of healthy eating among undergraduate university students in Finland? Cent Eur J Public Health 23: 306-313. Link: http://bit.ly/37TCrjq

5. Ozberak C (2010) The social factors of college lifestyle that may cause weight gain in undergraduate students. Perspectives 2: 20. Link: http://bit.ly/2PrLYI9

6. Fabian C, Pagan I, Rios JL, Betancourt J, Cruz SY, et al. (2013) Dietary patterns and their association with sociodemographic characteristics and perceived academic stress of college students in Puerto Rico. P R Health Sci J 32: 36-43. Link: http://bit.ly/3a5IYKj

7. Gan WY, Mohd NM, Zalilah MS, Hazizi AS (2011) Differences in eating behaviours, dietary intake and body weight status between male and female. Malaysian University students. Malays J Nutr 17: 213-228. Link: http://bit.ly/37VFzet

8. Freedman MR (2010) Development, evaluation, and validation of environmenta assessment tools to evaluate the college nutrition environment. J Am Coll Health 58: 565-568. Link: http://bit.ly/2Te802c

9. Sprake EF, Russell JM, Cecil JE, Cooper RJ, Grabowski P, et al. (2018) Dietary patterns of university students in the UK: a cross-sectional study. Nutrition Journal 17: 90. Link: http://bit.ly/39ZEtjk

10. Salameh P, Jomaa L, Issa C, Farhat G, Salame J, et al. (2014) Assessment of dietary intake patterns and their correlates among university students in Lebanon. Front Public Health 2: 185. Link: http://bit.ly/32svYe1

11. Kabir A, Miah S, Islam A (2018) Factors influencing eating behavior and dietary intake among resident students in a public university in Bangladesh: A qualitative study. PLoS one 13: e0198801. Link: http://bit.ly/37YDJtp

12. Janssen I, LeBlanc AG (2010) Systematic review of the health benefits of physical activity and fitness in school-aged children and youth. Int $\mathrm{J}$ Behav Nutr Phys Act 7: 40. Link: http://bit.ly/2PqbYUm

13. Chung QE, Abdulrahman SA, Khan MKJ, Sathik HBJ, Rashid A (2018) The Relationship between Levels of Physical Activity and Academic Achievement among Medical and Health Sciences Students at Cyberjaya University College of Medical Sciences. The Malays J Med Sci 25: 88-102. Link: http://bit.ly/32pEOtc

14. World Health Organization (2010) Global recommendations on physical activity for health. Geneva, Switzerland: WHO Press 1-60. Link: http://bit.ly/2uutcl

15. Ballard-Barbash R, Friedenreich CM, Courneya KS, Siddigi SM, McTiernan A et al. (2012) Physical activity, biomarkers, and disease outcomes in cancer survivors: a systematic review. J Natl Cancer Inst 104: 815-840. Link: http://bit.ly/380IT9B

16. Gunes-Bayir A, Kiziltan HS, Sentürk N, Mayadaglı A, Gumus M (2015) A pilot study of self-reported physical activity and eating habits in Turkish cancer patients under chemotherapy. Nutr Cancer 67: 906-911. Link: http://bit.ly/390wS3P

17. Pontifex MB, Saliba BJ, Raine LB, Picchietti DL, Hillman CH (2013) Exercise improves behavioral, neurocognitive, and scholastic performance in children with attention-deficit/hyperactivity disorder. J Pediatr 162: 543-551. Link: http://bit.ly/2uutsHG

18. Scheewe TW, Backx FJG, Takken T, Jörg F, van Strater AC, et al. (2013) Exercise therapy improves mental and physical health in schizophrenia: a randomised controlled trial. Acta Psychiatr Scand 127: 464-473. Link: http://bit.ly/2Ttnkbp

19. Verret C, Guay MC, Berthiaume C, Gardiner P, Béliveau L (2012) A physical activity program improves behavior and cognitive functions in children with ADHD: an exploratory study. J Atten Disord 16: 71-80. Link: http://bit.ly/2SXrXLF

20. World Health Organization (2019) "Physical activity" 29 May 2019, Link http://bit.ly/3a4SI6t

21. Kwan MY, Cairney J, Faulkner GE, Pullenayegum EE (2012) Physical activity and other health-risk behaviors during the transition into early adulthood: a longitudinal cohort study. Am J Prev Med 42: 14-20. Link: http://bit.ly/38ZFyrf

22. Güneş-Bayır A, Güçlü D (2019) Nutritional assessment and physical activity of the departments for Nutrition\&Dietetics and Nursing students at a foundation university. Bezmialem Science 7: 132-137. Link: http://bit.ly/32zBtrC

23. Baydemir C, Ozgur EG, Balci S (2018) Evaluation of adherence to Mediterranean diet in medical students at Kocaeli University, Turkey. J Int Med Res 46: 15851594. Link: http://bit.ly/2uzC9AE

Citation: Güneş-Bayir A, Alban ZH (2020) The comparison of nutritional and physical activity statuses in students of Audiology and Nutrition \& Dietetics. J Food Sci Nutr The 6(1): 001-006. DOI: https://dx.doi.org/10.17352/jfsnt.000018 
24. Arslan SA, Daşkapan A, Çakır B (2016) Üniversite öğrencilerinin beslenme ve fıziksel aktivite alışkanlıklarının belirlenmesi. TAF Preventive Medicine Bulletin 15: 171-180. Link: http://bit.ly/2Tg1h7F

25. Tözün M, Sözmen MK, Babaoğlu AB (2017) Türkiye'nin batısında bir üniversitenin sağlık ile ilişkili okullarında beslenme alışkanlıkları ve bunun obezite, fizik aktivite ve yaşam kalitesi ile ilişkisi. ESOGU Academic Open Access System. Link: http://bit.ly/2w1H0uJ

26. World Health Organization (2019) Body Mass Index-BMI. Link: http://bit.ly/3a9jqer

27. Pekcan G, Baysal A, Aksoy M, Besler HT, Bozkurt N, et al. (2013) Beslenme Durumunun Saptanması. Diyet El Kitabı 67-142.

28. Önal AE, Gürtekin B, Özel S, Erbil S, Ayvaz Ö, et al. (2013) Nutrition habıts and food consumption frequencies of medical faculty students. İstanbul Tıp Fakültesi Dergisi 76: 25-30. Link: http://bit.ly/3a91L6G

29. Sağlık Bakanlığı TC (2014) Beslenme durumu ve alışkanlıklarının değerlendirilmesi sonuç raporu. Türkiye Beslenme ve Sağlık Araştırması 2010 476-485. Link:

30. Mutlu E (2018) Medya araçlarının başkent üniversitesi öğrencilerinin beslenme davranışları ve gıda ürünlerinin seçiminde karar vermedeki etkisi. Master Thesis, Basket university Institute of Health Sciences 62-63. Link: http://bit.ly/37ZDIL9
31. Pektaş E, Cayir Y, Koşan Z (2017) Weight change and associated factors in Atatürk University Faculty of Medicine employees. Family Practice and Palliative Care 2: 1-4. Link: http://bit.ly/2Pn2b0X

32. Al-Shudifat AE, Al-Shdaifat A, Al-Abdouh AA, Aburoman MI, Otoum SM, et al. (2017) Diabetes risk score in a young student population in Jordan: a crosssectional study. J Diabetes Res 2017: 8290710. Link: http://bit.ly/386bv04

33. Ünal G, Uzdil Z, Kökdener M, Özenoğlu A (2017) Breakfast habits and diet quality among university students and its effect on anthropometric measurements and academic success. Progress in Nutrition 19: 154-162. Link: http://bit.ly/2SXIWgW

34. Comrie F, Masson LF, Mcneill G (2009) A novel online Food Recall Checklist for use in an undergraduate student population: a comparison with diet diaries. Nutr J 8: 13. Link: http://bit.ly/390zdvD

35. Sağlık Bakanlığı TC (2015) Türkiye Beslenme Rehberi (TUBER) 164-176. Link:

36. EFSA Panel on Dietetic Products, Nutrition, and Allergies (NDA) (2010) Scientific opinion on dietary reference values for carbohydrates and dietary fibre. EFSA J 8: 1462. Link: http://bit.ly/383s9gC

37. World Health Organization (2012) WHO Guideline: Sodium Intake for Adults and Children. Report Geneva 46. Link: http://bit.ly/37ZhyDm

38. Beslenme ve Diyetetik Bölümü, Hacettepe Üniversitesi Sağlık Bilimler Fakültesi (2015) Türkiye'ye Özgü Besin ve Beslenme Rehberi 19-35.
Discover a bigger Impact and Visibility of your article publication with Peertechz Publications

Copyright: @ 2020 Güneş-Bayir A, et al. This is an open-access article distributed under the terms of the Creative Commons Attribution License, which permits unrestricted use, distribution, and reproduction in any medium, provided the original author and source are credited.

Citation: Güneş-Bayir A, Alban ZH (2020) The comparison of nutritional and physical activity statuses in students of Audiology and Nutrition \& Dietetics. J Food Sci Nutr The 6(1): 001-006. DOI: https://dx.doi.org/10.17352/jfsnt.000018 